\title{
EFFECT OF PLANTING MEDIA ON THE GROWTH OF Shorea pinanga Scheff. SEEDLINGS
}

\author{
Diana Prameswari and M. Hesti Lestari Tata ${ }^{1}$
}

\begin{abstract}
Shorea pinanga Scheff. is a major tropical plant species which has an important economic value not only for timber, but also as illipe nut (called tengkawang in local name) production. This species is suggested for land rehabilitation and forest conservation. In rehabilitation action, S. pinanga is usually planted on the poor and degraded area. Application of chemical fertilizer and compost is used to increase the survival and growth of the seedlings. Excessive chemical fertilizer input to soil, however, may cause negative effect on soil, plant and environment. Conversely, compost may improve soil porosity, soil aggregate, water absorption and soil fertility. The objective of the study was to examine effect of planting media on growth of $S$. pinanga seedlings. Complete randomized design has been arranged with 5 treatments, e.g. soil mixed with husk (at the proportion of 1:1), soil mixed with acacia compost (1:1), soil mixed with charcoal of rice husk (1:1) and soil mixed with humic acid (1:1). Another treatment was soil alone used as control. The result showed that growth of both stem height and diameter, and index of seedling quality were affected significantly by planting media. The mixture of soil and acacia compost (1:1) was the best planting media for the growth of $S$. pinanga seedlings, which resulted in the growth of height $(24.19 \mathrm{~cm})$ and stem diameter $(0.246 \mathrm{~cm})$. Meanwhile, soil mixed with rice husk charcoal $(1: 1)$ gave the best result to the index of seedling quality (ISQ $=1.34)$ and total dry weight $($ TDW $=15.93 \mathrm{~g})$.
\end{abstract}

Keywords: Shorea pinanga, planting media, compost

\section{INTRODUCTION}

Dipterocarpaceae is the most common forest type in Indonesia. Nowadays, forest land has been under tremendous pressure due to over forest exploitation, fire and conversion to other land use type. Dipterocarp forest, which usually lies on ultisol soil type, may risk high nutrient losses to the streamflow with intensive disturbance (Malmer, 1996). Eventually, productivity of Dipterocarp forest may decrease fast and it will affect growth and yield of Dipterocarp trees or other species, which are planted as a plantation or rehabilitation program.

Shorea pinanga is one of the recommended species for forest plantation and rehabilitation program. This species produces not only major timber but also illipe nut, which is used as raw material for cosmetic, soap and margarine. Forest plantation and rehabilitation programs take the priority on the marginal land and bare land.

Land clearing, burning and other disturbances affect soil chemical properties and soil organic matters. Depletion of soil organic matter may cause negative impact on plant growth and yield (Sanchez, 1992). Fertilizer and compost are common practice to increase the survival and growth of the seedlings and juvenile plant. Excessive chemical fertilizer input to soil, however, may cause negative effect to soil, plant and environment. Whereas, compost may improve soil porosity, soil aggregate, water absorption and soil fertility (Buckman and Brady, 1982; Sanchez, 1992). The objective of the study was to examine the effect of planting media on the growth of $S$. pinanga seedlings.

1 Forest and Nature Conservation Research and Development Center, Bogor 


\section{MATERIAL AND METHODS}

\section{A. Materials}

Seeds of S. pinanga were collected from Darmaga Research Forest, Bogor. Rice husk charcoal, compost of Acacia's leaves, composted rice husk, humic acid ${ }^{\mathrm{TM}}$ were each amended to soil in the same mixing proportion (1:1).

\section{B. Methods}

The seeds were sown on sterilized sand in the seedbed. After a month, the seedlings were transplanted into soil already amended with rice husk charcoal, compost of Acacia's leaves, rice husk composted, humic acid ${ }^{\mathrm{TM}}$ each with the composition of 1:1. Soil which was not amended used as control. The study was conducted in the nursery of Forest and Nature Conservation Research and Development Center, Bogor, Indonesia.

The height and the stem diameter of the seedlings were measured once every month for a period of nine months. Nine months after transplanting, the total wet and dry weight of the seedlings were weighed and the ISQ was assessed using the method described by Dickson et al. (1960).

The experiment unit consisted of 14 seedlings regarded as replication, and the design used was the complete randomized design. The treatment on described before consisted of 5 kinds. The observed parameters were height, diameter, total dry weight, index quality of the seedlings. Further, soil physics and chemists properties were analyzed in Center for Soil and Agro-climate Research.

\section{RESULTS AND DISCUSSIONS}

\section{A. Growth of Seedling Height}

Planting media affected the growth of height of $S$. pinanga seedlings significantly. Soil amended with compost of Acacia gave the best result to height of $S$. pinanga seedlings (Figure 1).

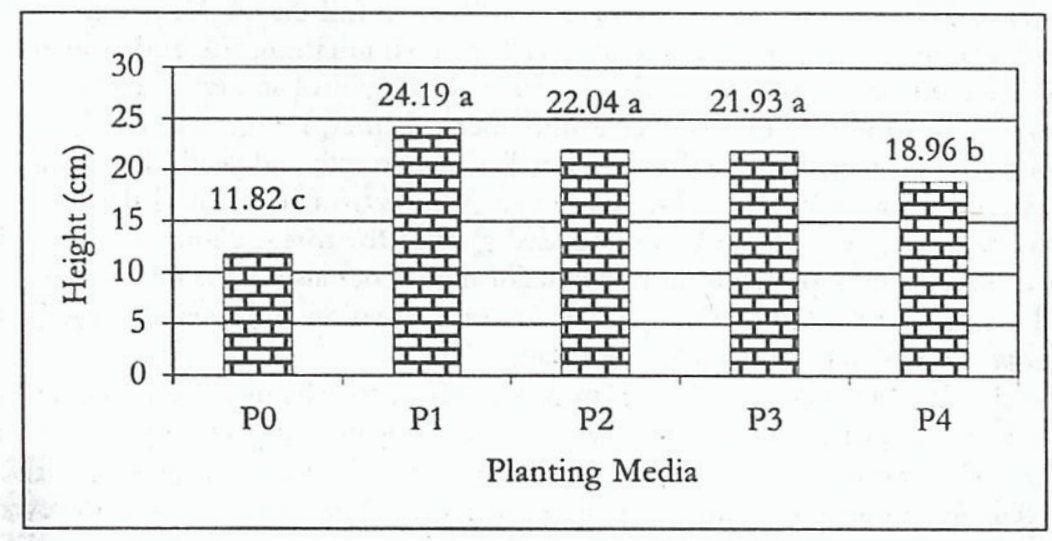

Figure 1. Histogram featuring height growth of $S$. pinanga seedling at 9 months after being transplanted on different planting media. $\mathrm{P} 0=$ control, $\mathrm{P} 1=$ Acacia compost amendment, P2= Rice husk compost amendment, P3 = charcoal of rice husk amendment, P4=humic acid amendment. Values followed by the same letter were not significantly different $(p<0.1)$ according to Duncan's Multiple Range Test 


\section{B. Growth of Stem Diameter}

Planting media affected significantly the growth of stem diameter of $S$. pinanga seedlings. Further, planting soil amended with compost of Acacia gave the best result to stem diameter of S. pinanga seedlings (Figure 2).

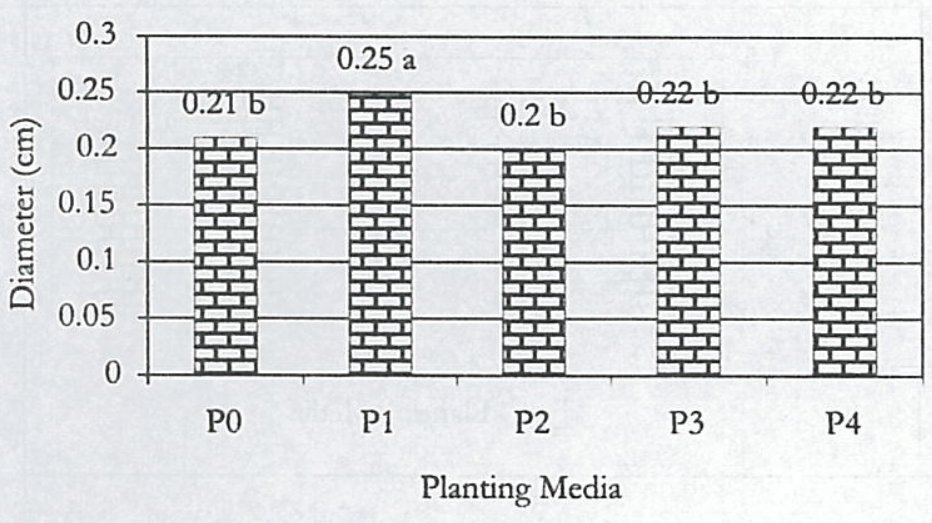

Figure 2. Histogram featuring stem diameter of $S$. pinanga seedling 9 months after being transplanted on different planting media. $\mathrm{P} 0=$ control, $\mathrm{P} 1=$ Acacia compost amendment, P2 = Rice husk compost amendment, $\mathrm{P} 3=$ charcoal of rice husk amendment, $\mathrm{P} 4=$ humic acid amendment. Values followed by the same letter were not significantly different $(\mathrm{p}<0.1)$ according to Duncan's Multiple Range Test

\section{Total Dry Weight (TDW)}

Dry weight is one of the important parameters, which reflects an interaction of genetic, environment and physiology process in the plant. TDW was significantly affected by the planting on growing media. Charcoal of rice husk gave the best result to TDW of $S$. pinanga seedlings (Figure 3).

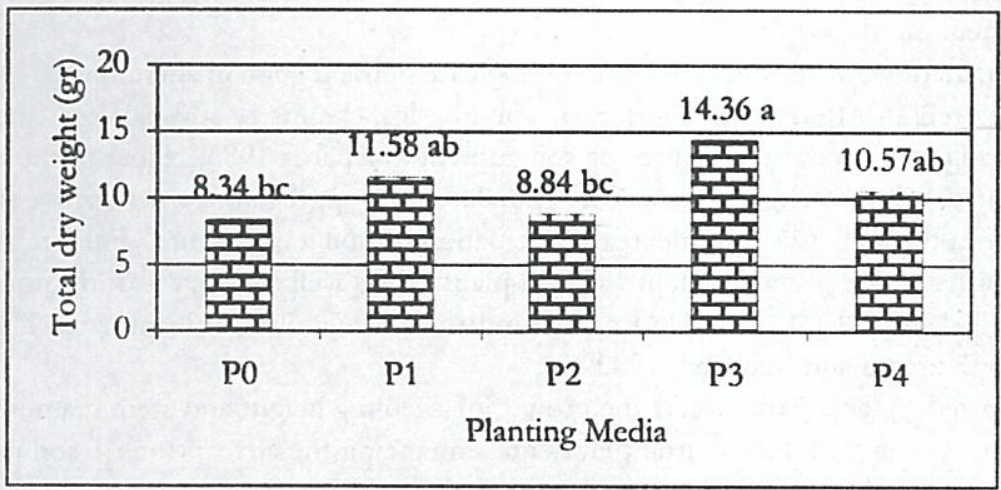

Figure 3. Histogram featuring total dry weight of $S$. pinanga at 9 months after being transplanted on different planting media. $\mathrm{P} 0=$ control, $\mathrm{P} 1=$ Acacia compost amendment, $\mathrm{P} 2=$ Rice husk compost amendment, $\mathrm{P} 3=$ charcoal of rice husk amendment, P4=humic acid amendment. Values followed by the same letter are not significantly different $(p<0.1)$ according to Duncan's Multiple Range Test 


\section{Index of Seedling Quality}

Index of seedling quality was affected significantly by the growing media. Soil amended with charcoal of rice husk gave the best index to seedling quality. On the other hand, soil amended with composted rice husk gave the poorest result (Figure 4).

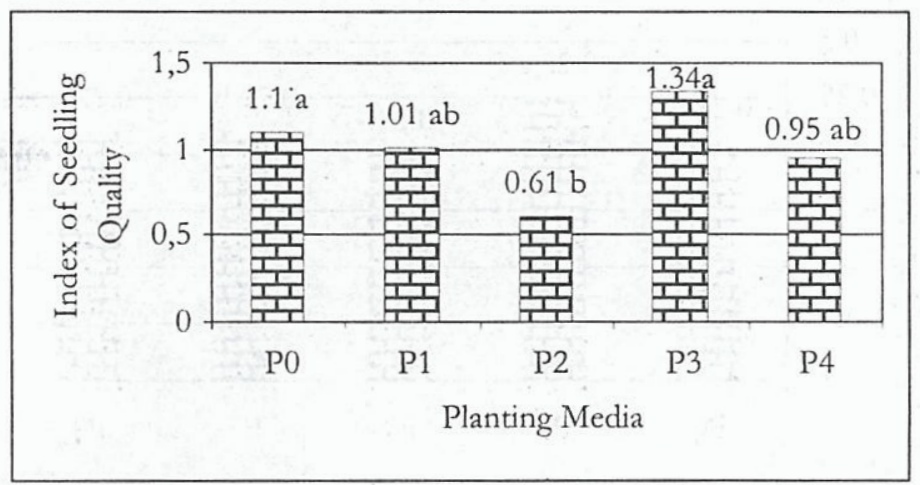

Figure 4. Histogram of index of featuring seedling quality of $S$. pinanga at 9 months after being transplanted on different planting media. $\mathrm{P} 0=$ control, $\mathrm{P} 1=$ Acacia compost amendment, P2= Rice husk compost amendment, P3 = charcoal of rice husk amendment, P4=humic acid amendment. Values followed by the same letter were not significantly different $(p<0.1)$ according to Duncan's Multiple Range Test

Planting media is one of the crucial steps in the development of plantation since it determines growth of the plants and their quality. Therefore, planting media should fulfill the requirement of both physical and chemical properties. Planting media affected growth of height, stem diameter and total dry weight very significantly, and affects index of seedlings quality significantly. Based on soil analysis, acidity of soil (5.4) is lower than that of both soil amended the composted Acacia (7.3) and soil amended with charcoal of rice husk (6.4). Meanwhile, acidity of both soil amended husk rice composted (4.3) and humic acid (4.16) was lower than that of control (soil without amendment).

Organic matter may prevent soil humidity, increase nutrient content and improve soil structure. Organic matters (OM) affect properties of soil physics, chemistry and biology, since OM acts as glue for soil aggregate and as source of soil nutrient (Soepardi, 1983). Fiber portion of organic matters may develop soil aggregate and its granulate. Soil aggregation will improve permeability and airflow in the soil. OM may decrease fluctuation of soil temperature. Further, root growth becomes easier to the particular depth so that plant grows well and may absorb more water and nutrient (Jo, 1990). OM may also improve nutrient availability, and improve P (phosphor) absorption (Karama and Manwan, 1990).

Composted Acacia bark affects the growth of seedling height and stem diameter. Besides, composted Acacia bark has neutral $\mathrm{pH}$, hence enhancing the adsorption of soil nutrients by plant easily. Amending the composted Acacia bark into the soil may improve its aeration and water holding capacity.

Humic acids is one of principal humic compounds in the soil. Humic acid has an important role for the soil microorganism. Humic acid is an inorganic acid which can improve permeability of plant cell membrane, improve production of chlorophyll, enhance photosynthesis, and stimulate 
hormone and enzyme activity (Bio Flora, 1997). In this study, soil amended with humic acid afforded good effect on the height growth and total dry weight of seedlings. Other study shows that humic acids applied in the medium without soil increase plant height, leaf area, and dry weight of peppers, tomatoes, and marigolds (Arancon et al., 2004).

Soil amended with the composted affected height of $S$. pinanga seedlings, whereas such amendment brought about the lowest index of seedling quality. Another study shows that the soil amended with composted rice husk afforded good result on the growth of $S$. javanica (Prameswari, 2004).

Husk of paddy rice may improve soil porosity, water content, pore of drainage, soil permeability and water availability, whereas weight of soil may decrease. Such may develop soil aggregation, and moreover it improves permeability and air flow in the soil. Raihan (1992) stated that husks of paddy rice affected physical properties of latosol soil with the clay texture more than $75 \%$.

The soil mixed with charcoal of husk of paddy rice resulted the most satisfactory total dry weight. Charcoal of paddy rice husk could absorb solar heat, and in return it improves soil temperature and accelerate plant growth. This is because charcoal of paddy rice husk absorbs toxic component in the soil and improve soil porosity (Supriyanto, 1999). Dry weight of seedlings is an indicator of successful interaction of plant with its environments, i.e. photosynthesis, physiology process and environment linkages interactions. Soil mixed with charcoal of husk of paddy rice brought out seedlings quality with the best index (1.34). The higher the index the better the seedling quality will be (Lackey and Alm, 1982).

\section{CONCLUSION}

1. Planting media affected significantly the growth of height and stem diameter, total dry weight and index of seedling quality of $S$. pinanga seedlings.

2. Soil amended with compost of Acacia's leaves afforded the best result on the height and stem diameter, i.e. $24.19 \mathrm{~cm}$ and $0.246 \mathrm{~cm}$ respectively. Meanwhile, soil amended with charcoal of rice husk did so on total dry weight (14.36) and index of seedling quality (1.34).

\section{REFERENCES}

Arancon, N.Q., S. Lee, C.A.Edwards and R. Atiyeh. 2004. Effects of humic acids derived from cattle, food and paper-waste vermicomposts on growth of greenhouse plants. Pedobiologia. January 2004. 47(5-6):741-744

Buckman, H.O and N.C. Brady. 1982. The Nature and Properties of Soil. PT Bharata. Jakarta (Translated to Bahasa Indonesia by Soegiman).

Bio Flora. 1997. Bio Flora International Breakthrough In Adding Humic Acid To Soil Biomass. Bio Flora International. Good Year. A.Z.

Dickson, A., A.L. Leaf and J.F. Hosner. 1960. Quality appraisal of white spruce and white pine seedling stocks in nurseries. Forest. Chron. 36(1):10-13.

Jo, I.S. 1990. Effect of organic fertilizer on soil physical properties and plant growth. Paper presented at seminar on "The use of organic fertilizers in crop production", at Suwon, South Korea, 18- 24 June. 1990. 25 p.

Karama, A.S. dan I. Manwan. 1990. Penggunaan pupuk organik pada tanaman pangan. Makalah pada Lokakarya Nasional Efisiensi Penggunaan Pupuk . Cisarua, Bogor. 12 -13 Nopember 1990. 44 pp. 
Lackey, M and A. Alm.1982 Evaluation of growing media for culturing containerized Red Pine and White Spruce. Tree Planters. Notes 33 (1): 3 - 7.

Malmer, A. 1996. Nutrient losses from Dipterocarps forests - A case study of forest plantation establishment in Sabah, Malaysia. In A. Schulte and D. Schone (Eds). Dipterocarp Forest Ecosystems. Towards Sustainable Management. World Scientific. Singapore. P:52-73.

Prameswari, D. 2004. Pengaruh inokulasi cendawan ektomikorhiza dan media tumbuh terhadap pertumbuhan Shorea javanica K and V. Thesis. Pascasarjana - IPB. Bogor

Raihan, H.S. 1992. Pengaruh sekam padi dan kapur terhadap kandungan hara tanaman, pertumbuhan dan hasil jagung serta kedelai. Thesis. Pascasarjana - IPB. Bogor.

Sanchez, P.A. 1992. Properties and Management of Soil in the Tropics. ITB Press. Bandung (Translated to Bahasa Indonesia by J.T. Jayadinata).

Soepardi, G. 1983. Sifat dan Ciri Tanah. Departemen Ilmu-ilmu Tanah, IPB, Bogor Supriyanto. 1999. The effectiveness of some ectomycorrhizal fungi in alginate beads promoting the growth of several Dipterocarps seedlings. Biotropika 12: 59-77. 